\title{
Monoclonal antibody localization of sperm surface antigen secreted by the epididymis of the baboon (Papio cynocephalus)
}

\author{
M. A. Isahakia \\ Institute of Primate Research, National Museums of Kenya, Box 24481 Karen, Nairobi, Kenya
}

\begin{abstract}
Summary. A monoclonal antibody (BSA6) was generated against an antigenic determinant secreted by the epididymis of the baboon and present on the acrosomal surface of the spermatozoa. This determinant was first secreted by the principal cells of the proximal corpus region, as determined by fluorescent microscopy performed on Bouinfixed epididymal tissue sections. The secretory product subsequently bound on the lateral acrosomal surfaces in the distal corpus region, but became uniformly distributed over the acrosomal region in the cauda epididymidis. The antigenic determinant had a molecular weight of 82000 (western blot technique). The testis, caput and other somatic tissues were devoid of the antigen, indicating the restriction of the antigen to spermatozoa and epithelial cells of the corpus epididymidis. Examination of similar tissue from immature baboons indicated that the secretion of this antigen was age-dependent, secretion beginning at about 4 years of age.
\end{abstract}

Keywords: monoclonal antibodies; baboon; epididymis; sperm maturation; acrosome.

\section{Introduction}

Mammalian spermatozoa acquire the ability to fertilize during passage through the epididymis (Blandau \& Rummery, 1964; Bedford, 1966; Orgebin-Crist, 1967; Moore, 1980, 1981). This occurs due to a number of physiological and biochemical changes that result in a negative surface charge (Bedford, 1963; Yanagimachi et al., 1972), alterations in the binding of different lectins (Nicolson \& Yanagimachi, 1972; Nicolson et al., 1977; Koehler, 1981) and the distribution and density of sperm surface antigens (Barker \& Amann, 1971; Killian \& Amann, 1973; Feuchter et al., 1981). For example, Lea et al. (1978) identified an acidic epididymal glycoprotein in the rat epididymis which was synthesized and secreted by the principal cells of the epithelium distal to the initial segment. Similar epididymal secretory proteins have been reported by others (e.g. proteins D and E: Cameo \& Blaquier, 1976; Gabriel et al., 1979; protein IV: Jones et al., 1980; sialoprotein: Faye et al., 1980; Bayard et al., 1981). To understand the precise role that these proteins play in events leading to fertilization, numerous investigations have been conducted to identify the major alterations in composition of the sperm plasma membrane during epididymal transit. Conventional antisera have been used in serological investigations of epididymal secretory products (Brooks \& Higgins, 1982), and monoclonal antibodies specific for epididymal sperm surface antigens have been investigated for the mouse (Vernon et al., 1982) and the hamster (Moore \& Hartman, 1984). In this study the origin of an epididymal secretory product of the baboon has been traced by using a monoclonal antibody.

\section{Materials and Methods}

Collection of spermatozoa. The epididymides of mature and immature baboons (Papio cynocephalus anubis) were obtained at autopsy from colony animals that had died of natural causes at the Institute. Precise ages of the animals 
and their breeding history were known. Each epididymis was carefully sectioned into caput, corpus and cauda regions. These were then sectioned into small portions and allowed to stand in Dulbecco's phosphate-buffered saline, pH 7.4 (DPBS) at $37^{\circ} \mathrm{C}$ for $1 \mathrm{~h}$. The DPBS was prepared according to Whittingham (1971).

The tissues were subsequently removed and the fluid centrifuged at $800 \mathrm{~g}$ for $10 \mathrm{~min}$. The supernatant was discarded and the pellet resuspended in phosphate-buffered saline (PBS) until used in the immunofluorescence assay.

Production of monoclonal antibody. Six female BALB/c mice (6-8 weeks old) were immunized intraperitoneally once a week with $5 \times 10^{6}$ spermatozoa from the cauda epididymidis of baboons for a period of 6 weeks. At 3 days after the final injection the mice were killed and the spleen cells were fused with $\mathrm{Sp} 2 / 0$ myeloma cells using the procedure of Galfre et al. (1977). Culture media were screened for antibody activity by the enzyme-linked immunoabsorbent assay described below. For ascites production cloned hybrids were expanded and ultimately injected into mice that had previously been injected intraperitoneally with pristane $(2,6,10,14-$ tetramethylpentradecane: Sigma Co., St Louis, MO, USA).

Enzyme-linked immunoabsorption assay (ELISA). Hybridoma supernatants were screened for antisperm activity 7-10 days after the fusion. Each well of a microtitre plate (Dynatec Labs Alexandria, VA, USA) was coated overnight at $4^{\circ} \mathrm{C}$ with $5 \times 10^{5}$ spermatozoa previously collected from the cauda epididymidis and washed once with PBS, pH 7.2. Antigen-coated plates were washed twice with $0.05 \%$ Tween (Sigma Chemicals Co., St Louis, MO, USA) in PBS and then with a $1 \%(\mathrm{w} / \mathrm{v})$ solution of polyvinyl alcohol (Sigma) in PBS/Tween buffer for 30 min. The wells were washed and then incubated with $100 \mu \mathrm{l}$ hybridoma supernatant overnight at $4{ }^{\circ} \mathrm{C}$. Following the overnight incubation, wells were washed three times with PBS/Tween and 100 $\mu$ l of a 1:500 dilution of rabbit anti-mouse immunoglobulins (IgG, IgM, IgA: Cappel Labs, Cochranville, PA, USA) were added to each well and incubated for $30 \mathrm{~min}$ at room temperature. The plates were then washed three times with PBS/Tween buffer and $100 \mu$ of Protein A- $\beta$-galactosidase conjugate (Zymed Labs, San Francisco, CA, USA) were added to each well at a dilution of 1:5000 in PBS/Tween buffer. The plates were incubated for $1 \mathrm{~h}$ at $37^{\circ} \mathrm{C}$ and then washed 5 times with Tween buffer. Substrate solution $(200 \mu \mathrm{l})$ containing $p$-nitrophenyl- $\beta$-galactopyranoside at $1 \mathrm{mg} / \mathrm{ml}$ (Sigma) was added to each well and incubated at $37^{\circ} \mathrm{C}$. Upon colour development, the absorbance was determined with a FLOW ELISA reader using a $405 \mathrm{~nm}$ filter.

Determination of immunoglobulin class. The class and subclass of the secreted monoclonal antibody was determined by Ouchterlony double immunodiffusion using commercial class and isotype specific antisera (Serotec Labs, Kidlington, Oxford, UK).

Sperm immunofluorescence. Spermatozoa collected from the caput, corpus and cauda epididymidis were washed three times with Tyrode's solution and then reacted with culture supernatants or ascites fluid in an equal volume of Tyrode's solution for $45 \mathrm{~min}$ (Feuchter et al., 1981). All incubations were done in the presence of bovine serum albumin (BSA) and $0.1 \%$ sodium azide at $4 \%$.

After three washings the spermatozoa were incubated for $30 \mathrm{~min}$ at $4{ }^{\circ} \mathrm{C}$ in a dilution of fluorescein-isothiocynate conjugated (FITC conjugate) goat anti-mouse immunoglobulins (IgG, IgM, IgA; Cappel Laboratories), washed three times and viewed by fluorescent microscopy. The above assay was also carried out on paraformaldehyde-fixed spermatozoa that had been incubated with Tyrode's solution containing $5 \%$ BSA. Negative controls used in the assays included $\mathrm{Sp} 2 / 0$ myeloma culture supernatant or ascites fluid. A positive control antibody, BSA4, that recognised testicular antigens was also used.

Immunocytochemical staining. Testicular and epididymal tissues from adult and immature baboons were obtained at autopsy. The epididymis was sectioned into caput, corpus and caudal regions. These tissues were then dehydrated through a $70 \%$ to $100 \%$ ethanol series, cleared in toluene and embedded in paraffin wax $\left(55^{\circ} \mathrm{C}\right)$. Tissue sections $(4 \mu \mathrm{m})$ were mounted on glass slides and deparaffinized in 2 changes of xylene. The tissues were then washed in a graded series of ethanol mixtures and incubated for $30 \mathrm{~min}$ at $4^{\circ} \mathrm{C}$ with DPBS containing $5 \%$ normal rabbit serum. After washing the sections were incubated with $50 \mu$ culture supernatant, or control negative and positive supernatants, in a humid chamber overnight at $4^{\circ} \mathrm{C}$. The tissue sections were then washed for $30 \mathrm{~min}$ and incubated in the dark for $45 \mathrm{~min}$ at $4^{\circ} \mathrm{C}$ with $50 \mu$ FITC-conjugated goat anti-mouse immunoglobulins diluted 1:40 in DPBS plus $5 \%$ rabbit serum. The slides were then washed for $30 \mathrm{~min}$, blotted and coverslips mounted with mounting medium $(9 \mathrm{vol}$. glycerol $/ 1 \mathrm{vol}$ $0.05 \mathrm{M}$-Tris buffer $\mathrm{pH} 9.5$.

The sections were examined and photographs were taken using a Wild-Leitz epifluorescence microscope. Fluorescence photographs were taken using Kodak Tri-X pan 400 black and white films.

Control tissues used were Bouin-fixed kidney, liver and lung.

Sodium dodecylsulphate polyacrylamide gel electrophoresis/western blot. Slab gel electrophoresis to analyse detergent ( $1 \%$ Triton X-100)-derived sperm membrane extracts was carried out according to the method of Laemmli (1970) using 10\% gels. Separated proteins were subsequently transferred electrophoretically onto nitrocellulose paper as described by Towbin et al. (1979) and identified by staining with amido black ( $0 \cdot 1 \%$ amido black in $45 \mathrm{methanol} /$ $10 \%$ acetic) acid for $3 \mathrm{~min}$.

The transferred proteins on the nitrocellulose were incubated in PBS $/ 0 \cdot 15 \%$ Tween buffer at room temperature for $4 \mathrm{~h}$ to block non-specific binding sites. The paper was then cut into strips $(0.2-0.4 \mathrm{~mm})$ and then incubated with antibody-containing hybridoma supernatants overnight at $4^{\circ} \mathrm{C}$. Control myeloma supernatant was also included. The strips were washed in PBS/0.15\% Tween buffer for $30 \mathrm{~min}$ with three changes and then incubated with peroxidaseconjugated goat anti-mouse immunoglobulin (1:500 dilution in PBS/0.1\% Tween buffer pH 7.2 ) for $30 \mathrm{~min}$ at room temperature. After washing the strips with several changes of the washing buffer the strips were incubated with 

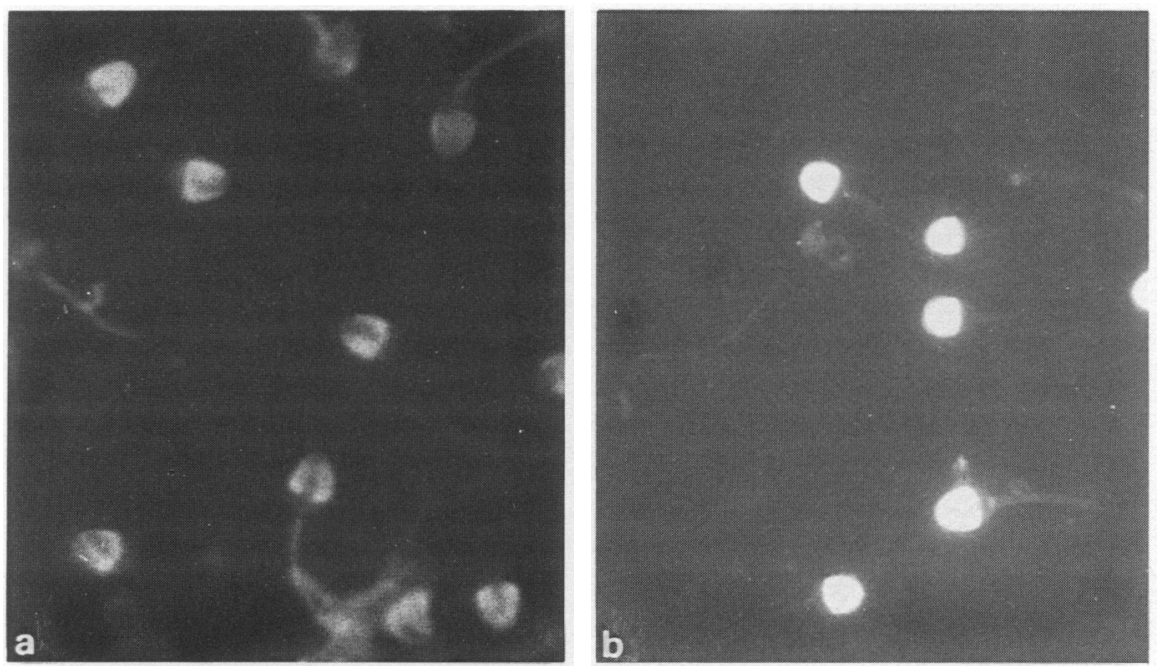

Fig. 1. Immunofluorescent localization of antibody BSA6 on spermatozoa from the distal corpus epididymidis (a) and the cauda epididymidis (b). In (a) fluorescence was localized only on the lateral aspects of the sperm acrosome region. In (b) fluorescence was distributed uniformly on the entire acrosome. $\times 800$.

4-chloronaphthol $\left(0.6 \mathrm{mg} / \mathrm{ml}\right.$ in $20 \%$ methanol Tris buffer saline $\left.0.01 \% \mathrm{H}_{2} \mathrm{O}\right)$. The strips were washed and then photographed while wet.

\section{Results}

Of the 960 putative hybrids from two fusions carried out, only 35 secreted antibodies that were specific for spermatozoa. Of these 35 clones only one (BSA6) reacted with epididymal but not testicular spermatozoa as determined in the ELISA and immunofluorescence assays. The class of the monoclonal antibody BSA6 was IgG as determined in the Ouchterlony test.

\section{Sperm immunofluorescence}

Antibody BSA6 strongly reacted with the acrosomal region of baboon cauda epididymal spermatozoa. Approximately $80 \%$ of unfixed spermatozoa demonstrated this staining pattern. There was no staining of paraformaldehyde-fixed spermatozoa. While the antibody in spermatozoa from the distal corpus was restricted to the lateral aspects of the sperm head (Fig. 1a), spermatozoa from the cauda epididymidis displayed a more uniform antibody binding pattern (Fig. 1b). There was no antibody reactivity with spermatozoa obtained from the caput regions of the epididymis. In contrast, the control positive antibody BSA4 reacted only with epididymal spermatozoa and not the principal cells. There was no staining of spermatozoa with the Sp2/0 myeloma supernatant.

\section{Tissue immunohistochemistry}

To determine the origin of the antigenic determinants recognized by Antibody BSA6, Bouinfixed epididymal (caput, corpus and cauda) and testicular sections were reacted with the antibody (Table 1). Antibody BSA6 reacted first with the proximal corpus tissue, staining the adluminal region of the principal cells (Fig. 2). The apical cytoplasm immediately beneath the stereocilia of the principal cell was labelled in a granular fashion (Fig. 3). The transition between the apical 

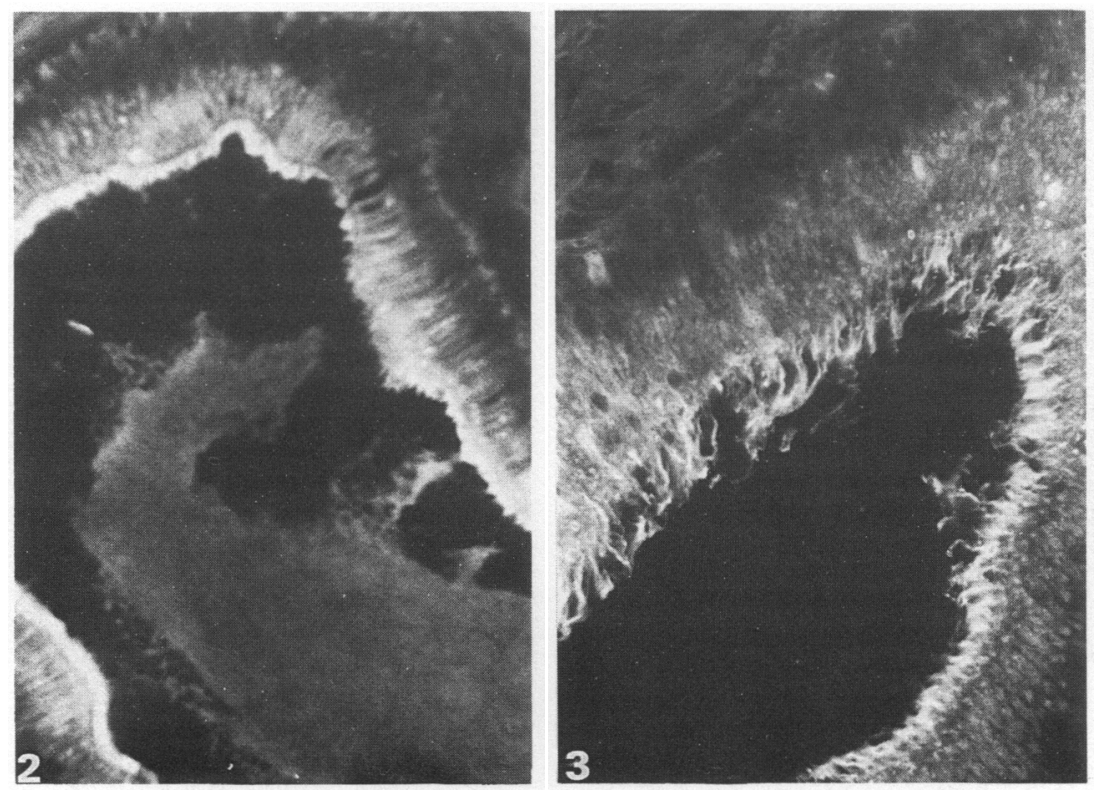

Fig. 2. Immunofluorescent localization of antigenic determinant to BSA6 antibody in the proximal corpus epididymidis of Bouin-fixed tissue. The fluorescence was restricted to the proximal third of the epithelial cells. Also note the lack of sperm staining in the lumen of the tubule. There is some non-specific staining of the connective tissue observed even with fluorescein isothyocynate conjugate alone. $\times 450$.

Fig. 3. Immunofluorescent localization of secretory antigen within the apical cytoplasm of principal cells of the distal corpus. Note the brightly fluorescent granular cytoplasmic staining in addition to that of the stereocilia. $\times 450$.

cytoplasmic staining and the lack of basal staining was quite distinct, appearing as a line which could be traced around a given tubular cross-section. This staining pattern was observed in all the duct profiles examined in the corpus region. At the proximal corpus level only the epithelial cells displayed antibody binding while the luminal spermatozoa lacked any staining. More distally, however, while the epithelial cells continued to react with the antibody, spermatozoa in the lumen were also stained (Fig. 4).

Antibody BSA6 also reacted with cauda epididymal tissue. However, the antibody staining was restricted to the microvilli of the epithelial cells (Fig. 5). There was no staining of other tissues tested, including the initial segment. The spermatozoa in the lumen continued to be fluorescent in the ductus deferens even though there was no epithelial staining. There was no staining of testicular, liver and lung sections by Antibody BSA6. The control testis-specific antibody BSA4 reacted only with luminal spermatozoa in all the regions of the epididymis (Fig. 6a, b); there was no staining of the epithelial cells. Indirect immunofluorescence assays were performed on epididymal tissue from 2-, 3- and 4-year-old baboons. Sections of epididymis from 2- and 3-year-old baboons did not express the antigen but the epididymis from 4-year-old baboons gave a labelling pattern of the epithelium similar to that of mature adults.

\section{Antigen specificity of the monoclonal antibody}

The molecular weight of the antigenic determinant recognized by Antibody BSA6 was investigated by SDS-PAGE analysis of detergent-derived membrane proteins of cauda epididymal 

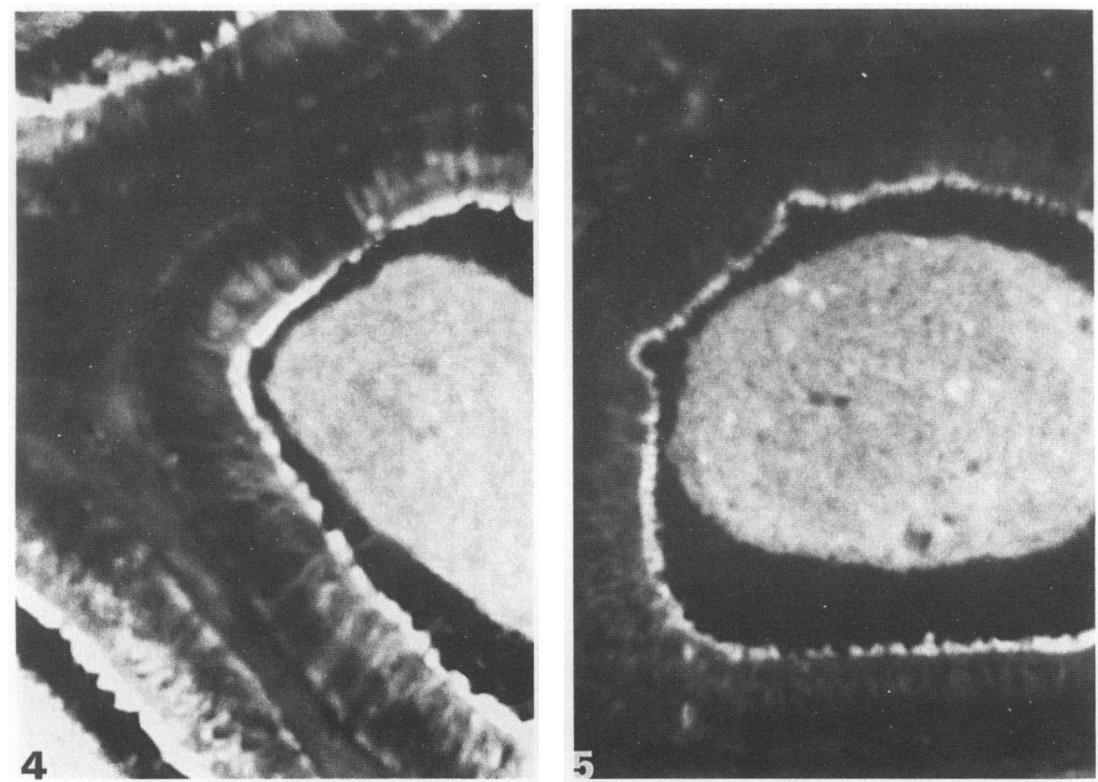

Fig. 4. Immunofluorescent localization of secretory antigen on luminal spermatozoa in the distal corpus. $\times 450$.

Fig. 5. Immunofluorescent localization of secretory antigen in the stereocilia and the spermato zoa in the lumen of the cauda epididymidis. Note the lack of cytoplasmic staining. $\times 450$.
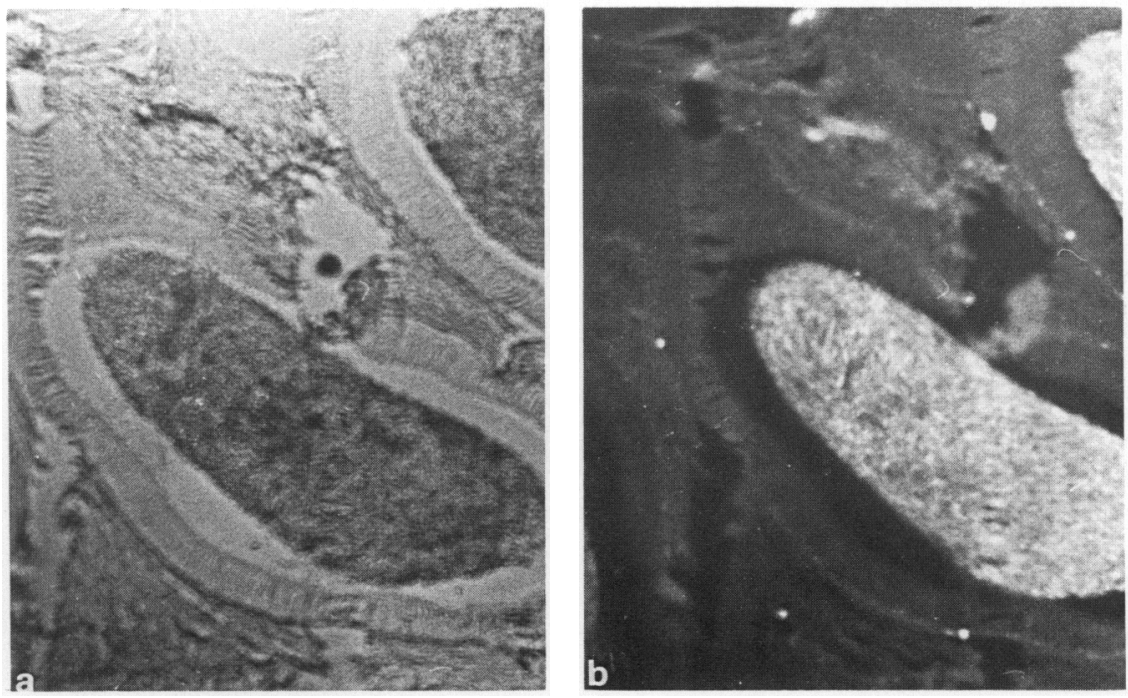

Fig. 6. Sections of the proximal corpus region: (a) phase-contrast microscopy and (b) immunofluorescent localization of the testicular sperm antigen shown by positive control antibody BSA4. Note the lack of epithelial staining. The fluorescence is restricted to the spermatozod in the lumen. $\times 300$.

spermatozoa (Fig. 7a) and then, by electrophoretic transfer to nitrocellulose, Antibody BSA6 reacted with a determinant with a molecular weight of 82000 (Fig. 7b). Control myeloma supernatant did not react with any antigen (Fig. $7 \mathrm{c}$ ). 
Table 1. Distribution of sperm surface binding antigen in the baboon reproductive tract

\begin{tabular}{lccc}
\hline $\begin{array}{l}\text { Region of } \\
\text { epididymis }\end{array}$ & Spermatozoa & $\begin{array}{c}\text { Epithelial cell } \\
\text { stereocilia }\end{array}$ & $\begin{array}{c}\text { Epithelial } \\
\text { cell }\end{array}$ \\
\hline Initial segment & - & - & - \\
Proximal caput & - & - & - \\
Distal caput & - & - & - \\
Proximal corpus & - & + & + \\
Distal corpus & + & + & + \\
Proximal cauda & + & + & - \\
Distal cauda & + & \pm & - \\
Ductus deferens & + & - & - \\
\hline
\end{tabular}

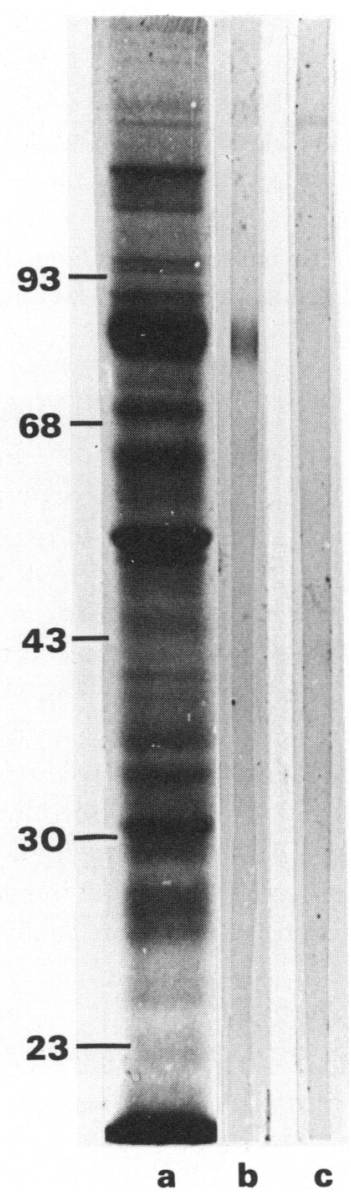

Fig. 7. SDS/Polyacrylamide gel electrophoresis of detergent-solubilized ( $1 \%$ Triton X-100) membrane extract of cauda epididymal spermatozoa. Lane a, Coomassie blue stain of separated sperm proteins; Lane b, Antibody BSA6-reacted material, showing an antigen with a molecular weight of 82000 ; Lane c, control myeloma supernatant showing no reaction with antigen. 


\section{Discussion}

Over the past few years much evidence has accumulated that factors secreted by epididymal epithelium under the control of androgens alter the sperm surface. The exact mechanism involved in the maturation of spermatozoa in the epididymis is unclear but antigenic moieties are believed to be transferred in the proximal corpus epididymidis from the apical surface of epithelial principal cells to the sperm plasma membrane. Studies with monoclonal antibodies in the mouse (Vernon et $a l ., 1982$ ) and the hamster (Moore \& Hartman, 1984) indicate that the corpus region of the epididymis secretes sperm binding determinants that are distributed over the sperm surface or restricted to the tail. An epididymal secretory antigen that is restricted to the post-acrosomal plasma membrane of spermatozoa has also been reported for the hamster (Smith et al., 1986).

The determinant of $M_{\mathrm{r}} 82000$ first secreted by the principal cells of the proximal corpus epididymidis of the baboon is only associated with the sperm acrosome in the more distal regions of the corpus epididymidis. The absence of this determinant on spermatozoa in the proximal corpus region in the presence of active epithelial secretion suggests a lag between secretion and its subsequent association with the sperm surface. This observation for the baboon supports the findings of Vernon et al. (1982) for the mouse and Moore (1980) for the hamster. The mechanism of and the regional epithelial specifications for secretion of sperm-associated antigens in the epididymis are therefore probably similar amongst mammals. This determinant specifically associates with the plasma membrane of the sperm acrosome but undergoes a change in its distribution pattern as spermatozoa reach the cauda epididymidis. We do not know the significance of this redistribution on the antigens or even how the secretory product associates only with the sperm acrosome. One attractive hypothesis is the presence of specific acceptor sites of molecules for the secretory product only on the sperm acrosome (Vernon et al., 1982). This would account for the lack of antigens on the rest of the sperm surface. In the mouse (Vernon et al., 1982), the secretory antigen SMA4 is restricted to the tail region even though it appeared in the corpus region in a manner similar to the baboon secretory protein of $M_{\mathrm{r}} 82000$. Muller \& Eddy (1984) have also reported an acrosomebinding molecule (SMA6) secreted by the epididymis in the mouse, but the molecular size of SMA6 has not yet been established. In the baboon, the $M_{\mathrm{r}} 82000$ determinant first appears at the age of 4 years, an age when spermatogenesis commences (Chowdhury \& Steinberger, 1976).

The staining of all sterocilia in the cauda epithelial cells could represent the initial stages of active absorption and degradation of excess secretory antigen produced in the more proximal corpus regions of epididymis. Absorption of luminal material has previously been shown to occur in most areas of the male reproductive tract (Nicander et al., 1965; Friend, 1969). The presence of cytoplasmic staining only in the corpus epithelial cells suggests that the antigen of $M_{\mathrm{r}} 82000$ is synthesized and secreted by the cells. The functional role of this antigen is unknown. However, previous studies have shown the association of absorption with the acquisition of fertilizing ability of the spermatozoa in the epididymal duct. Some of these epididymal proteins may therefore play an important role in the development of sperm motility and in sperm-egg interactions (Hoskins et al., 1978; Oliphant \& Singhas, 1979; Hinrichsen \& Blaquier, 1980; Saling, 1982; Voglmayr et al., 1985).

Financial support was received from the Rockefeller Foundation and the World Health Organisation, Special Programme for Research, Development and Training in Human Reproduction.

\section{References}

Barker, L.D.S. \& Amann, R.P. (1971) Epididymal physiology II. Immunoftuorescence analysis of epithelial secretion and absorption, and of bovine maturation. J. Reprod. Fert. 26, 319-332.

Bayard, F., Duguel, L., Mazzuca, M. \& Faye, J.C. (1981) Study of a glycoprotein produced by the rat epididy- mis. In Reproductive Processes and Contraception, pp. 393-411. Ed. K. W. McKerns. Plenum, New York.

Bedford, J.M. (1963) Changes in electrophoretic properties of rabbit spermatozoa during passage through the epididymis. Nature, Lond. 200, 1178-1180.

Bedford, J.M. (1966) Development of the fertilizing 
ability of spermatozoa in the epididymis of the rabbit. J. exp. Zool. 163, 319-329.

Blandau, R.J. \& Rummery, R.E. (1964) The relationship of swimming movements of spermatozoa to their fertilizing capacity. Fert. Steril. 15, 571-479.

Brooks, D.E. \& Higgins, S.J. (1982) Characterization of androgen-dependence of proteins associated with luminal fluid and spermatozoa in a rat epididymis. $J$. Reprod. Fert. 59, 363-375.

Cameo, M.S. \& Blaquier, J.A. (1976) Androgen controlled specific proteins in rat epididymis. $J$. Endocr. 69, 47-54.

Chowdhury, A.K. \& Steinberger, E. (1976) A study of germ cell morphology and duration of spermatogenic cycle in the baboon (Papio anubis). Anat. Rec. 185, $115-170$.

Faye, J.C., Duguet, L., Mazzuca, M. \& Bayard, F. (1980) Purification radioimmunoassay and immunohistochemical localization of a glycoprotein produced by rat epididymis. Biol. Reprod. 23, 423-432.

Feuchter, F.A., Vernon, R.B. \& Eddy, E.M. (1981) Analysis of the sperm surface with monoclonal antibodies: topographically restricted antigens appearing in the epididymis. Biol. Reprod. 24, 1099-1110.

Friend, D.S. (1969) Cytochemical staining of multivesicular body and golgi vesicles. J. Cell Biol. 42, $269-279$.

Gabriel, J.C., Kohane, A.C., Cameo, M.S. \& Blaquier, J.A. (1979) Isolation and characterization of specific rat epididymal proteins. Molec. cell. Endrocrinol. 13, $73-82$.

Galfre, G., Howe, S.C., Milstein, C., Butcher, G.W. \& Howard, J.C. (1977) Antibodies to major histocompatibility antigens produced by hybrid cell lines. Nature, Lond. 226, 550-552.

Hinrichsen, M.J. \& Blaquier, J.A. (1980) Evidence supporting the existence of sperm maturation in the human epididymis. J. Reprod. Fert. 60, 291-294.

Hoskins, D.D., Brandt, H. \& Accot, T.S. (1978) Initiation of sperm motility in the mammalian epididymis. Fedn Proc. Fedn Am. Socs exp. Biol. 37, 2534-2536.

Jones, R., Brown, C.R., Von Glos, K.I. \& Parker, M.G. (1980) Hormonal regulations of protein synthesis in the rat epididymis. Characterization of androgen dependent and testicular fluid-dependent protein. Biochem. J. 188, 667-676.

Killian, G.J. \& Amann, R.P. (1973) Immunoelectrophoretic characterisation of fluid and sperm entering and leaving the bovine epididymis. Biol. Reprod. 9, $489-499$.

Koehler, J.K. (1981) Lectins as probes of the spermatozoan surface. Archs Androl. 6, 197-217.

Laemmli, U.K. (1970) Cleavage of structural proteins during the assembly of the head of bacteriophage TU. Nature, Lond. 227, 680-685.

Lea, O.A., Petrusz, P. \& French, F.S. (1978) Purification of localization of acidic epididymal glycoprotein (AEG): a sperm coating protein secreted by the rat epididymis. Int. J. Androl., Suppl. 2, 592-607.

Moore, H.D.M. (1980) Localization of specific glycoproteins secreted by the rabbit and hamster epididymis. Biol. Reprod. 22, 705-718.
Moore, H.D.M. (1981) Glycoprotein secretion of the epididymis in rabbit and hamster: location of the epididymal spermatozoa and the effect of specific antibodies on fertilization in vivo. J. exp. Zool. 2 , $77-85$.

Moore, H.D.M. \& Hartman, T.D. (1984) Localization by monoclonal antibodies of various surface antigens of hamster spermatozoa and the effect of antibody on fertilization in vitro. J. Reprod. Fert. 70, 175-183.

Muller, C.H. \& Eddy, E.M. (1984) Localisation of sperm surface molecule in epididymis. Ann. N.Y. Acad. Sci. 438, 533-534.

Nicander, L., Paulsson, S. \& Selander, U. (1965) An electron microscopical study of iron absorption in the epididymal tail of rabbit. Scand. Congr. Cell Res. 4, $51-52$.

Nicolson, G.L. \& Yangimachi, R. (1972) Terminal saccharides on sperm plasma membrane: identification using specific agglutins. Science, N.Y. 177, 276-279.

Nicolson, G.L., Usui, N., Yanagimachi, R., Yanagimachi, H. \& Smith, J.R. (1977) Lectin binding sites on the plasma membrane of rabbit spermatozoa. J. Cell Biol. 74, 950-962.

Oliphant, G. \& Singhas, C.A. (1979) Iodination of rabbit sperm plasma membrane: relationship of specific surface proteins to epididymal function and sperm capacitation. Biol. Reprod. 21, 937-944.

Orgebin-Crist, M.C. (1967) Sperm maturation in rabbit epididymis. Nature, Lond. 216,816-818.

Saling, P.M. (1982) Development of the ability to bind to zonae pellucidae during epididymal maturation: reversible immobilization of mouse spermatozoa by lanthanum. Biol. Reprod. 26, 429-434.

Smith, C.A., Hartman, T.D. \& Moore, H.D.M. (1986) A determinant of $M_{\mathrm{r}} 34000$ expressed by hamster epididymal epithelium binds specifically to spermatozoa in co-culture. $J$. Reprod. Fert. 78, 337-345.

Towbin, H., Staehelin, T. \& Gordon, J. (1979) Electrophoretic transfer of proteins from polyacrylamide gels to nitrocellulose sheets: Procedure and some applications. Proc. natn. Acad. Sci. USA 79, 43504354.

Vernon, R.B., Muller, C.H., Herr, J.C., Feuchter, F.A. \& Eddy, E.M. (1982) Epididymal secretion of a mouse sperm surface component recognized by a monoclonal antibody. Biol. Reprod. 26, 523-535.

Voglmayr, J.K., Sawyer, R.F. \& Dacheux, J.L. (1985) Glycoprotein: a variable factor in surface transformation of ram spermatozoa during epididymal transit Biol. Reprod. 33, 165-176.

Whittingham, D.G. (1971) Survival of mouse embryos after freezing and thawing. Nature, Lond. 233, 125 126.

Yanagimachi, R., Noda, Y.D., Fujimoto, M. \& Nicolson, G.L. (1972) The distribution of negative surface changes on mammalian spermatozoa. Am. J. Anat. $135,497-452$.

Received 27 June 1988 